\title{
Ethnobotanical Study of Underutilized Wild Edible Fruits and their Antibacterial Activity against Human Pathogens
}

\author{
Suresh Ch. Biswas ${ }^{1,4}(\mathbb{D})$, Pranab Dutta ${ }^{2 *}$ (D) Purnima Barua ${ }^{3}$, \\ Tarun Kr. Misra ${ }^{4}\left(\mathbb{D}\right.$ and Subrata Das ${ }^{5}$ (iD \\ ${ }^{1}$ Krishi Vigyan Kendra, Khowai - 799 207, Tripura, India. \\ ${ }^{2}$ School of Crop Protection, College of Post Graduate Studies in Agricultural Sciences, Central Agricultural \\ University, Umiam - 793 103, Meghalaya, India. \\ ${ }^{3}$ Department of Microbiology, Jorhat Medical College Jorhat - 785 001, Assam, India. \\ ${ }^{4}$ Department of Chemistry, National Institute of Technology Agartala - 799 046, Tripura, India. \\ ${ }^{5}$ Department of Chemistry, National Institute of Technology Patna - 800 005, Bihar, India.
}

\begin{abstract}
Nine underutilized wild edible fruits collected from four districts of Tripura, a North-Eastern state of India were studied for the antibacterial properties against five (5) human pathogens, Escherichia coli (Gram-Ve, ATCC-2522), Pseudomonas aeruginosa (Gram-Ve, ATCC-27853), Salmonella typhi (Gram-Ve, ATCC-14028), Staphylococcus aureus (Gram +Ve, ATCC-25923) and Klebsiella pneumonia (Gram-Ve, ATCC-700603) by disk diffusion method. Besides, the folk medicinal values and their ethnobotanical importance are also reported. Out of the nine (9) wild edible fruits, $C$. macroptera and $S$. dulcis showed the least antibacterial effect against all the bacterial pathogens under the present study. On the other hand, G. gummi-gutta and A. lacucha showed considerable antibacterial effects against all of the bacterial pathogens with the highest zone of inhibition against $E$. coli, followed by $P$. aeruginosa. Selective inhibitory effect of some of the wild edible fruits was also observed against the targeted pathogens. This study paves the way for using the underutilized wild fruits of the North-Eastern region of India as a potential source of antipathogenic activity of human pathogens. Further, a detailed study may help in identifying the bioactive compound of industrial importance.
\end{abstract}

Keywords: Wild edible fruits, ethnobotanical, antibacterial activity

*Correspondence: pranabdutta74@gmail.com

(Received: June 26, 2021; accepted: September 06, 2021)

Citation: Biswas SC, Dutta P, Barua P, Misra TK, Das S. Ethnobotanical Study of Underutilized Wild Edible Fruits and their Antibacterial Activity against Human Pathogens. J Pure Appl Microbiol. 2021;15(4):1976-1986. doi: 10.22207/JPAM.15.4.19

(C) The Author(s) 2021. Open Access. This article is distributed under the terms of the Creative Commons Attribution 4.0 International License which permits unrestricted use, sharing, distribution, and reproduction in any medium, provided you give appropriate credit to the original author(s) and the source, provide a link to the Creative Commons license, and indicate if changes were made. 


\section{INTRODUCTION}

The North-Eastern States of India is rich of natural plant products which have tremendous ethnobotanical value but unexplored. Searching for alternatives of antibacterial synthetic drugs is a paramount area of research. The wild eatable fruits have incredible potential for creating new medications to human well-being. There are numerous wild fruits utilized in medicine today, which initially got from plant sources. A large portion of medications' inception from plants of a restorative worth offers new wellsprings of drugs, which have been utilized successfully in daily medicine..$^{1,2}$ Plant origin antibacterial property has massive remedial possibilities and is viable in treating irresistible ailments than engineered antimicrobials, which have antagonistic impacts. ${ }^{3,4}$ Examination laborers announced the elite of dynamic plants having 157 families $^{5}$ and the antimicrobial movement. ${ }^{6-10}$ The issue of microbial obstruction is developing, and the stand point for the utilization of antimicrobial drugs, later on is unsure. Thus, documentation of ethnobotanical value of the plant products and investigation on their antibacterial properties could be beneficial to the society. Tripura, a North-Eastern part of India, is mostly hilly with dense forest. Among the eight (8) districts, four (4) including Khowai, Dhalai, West Tripura and Sipahijala districts were selected for sample collection sites (Fig. 1) as this areas are rich in wild fruit plants which have been used by the tribal people to meet their nutrition and medicines. The huge knowledge on the prevailing wild fruits helped us to choose the different fruits for the present study.

Recently, we have documented the ethnobotanical value of some fruits. ${ }^{11}$ Nevertheless, the restorative estimation of wild edible fruits lies in their ingredients like alkaloids, flavonoids, tannins and phenolic derivatives, and that produce a specific physiological activity on the human body. ${ }^{12}$ Polyphenols from the wild fruits have a few advantages, including antimicrobial properties against pathogenic and waste microorganisms and varieties in these mixes' concoction creations to prompt marked contrasts in their antimicrobial action. ${ }^{13-15}$ In this paper we have reported the antibacterial properties of the nine (9) underutilized wild fruits viz., G. gummigutta, P. serratum, S. suaveolens, F. jangomas, $S$. assamicum, S. dulcis, A. lacucha, F. hispida, and C. macroptera a gainst 5 human pathogens viz., E. coli, $P$. aeruginosa, S. typhi, S. aureus and $K$. pneumonia. Additionally, the ethnobotanical value of the four (4) unexplored fruits: F. jangomas, $S$. dulcis, A. lacucha and F. hispida has also been documented.

\section{MATERIALS AND METHODS \\ Sample collection}

Field visits were made to conduct surveys to different villages and forest areas of four (4)

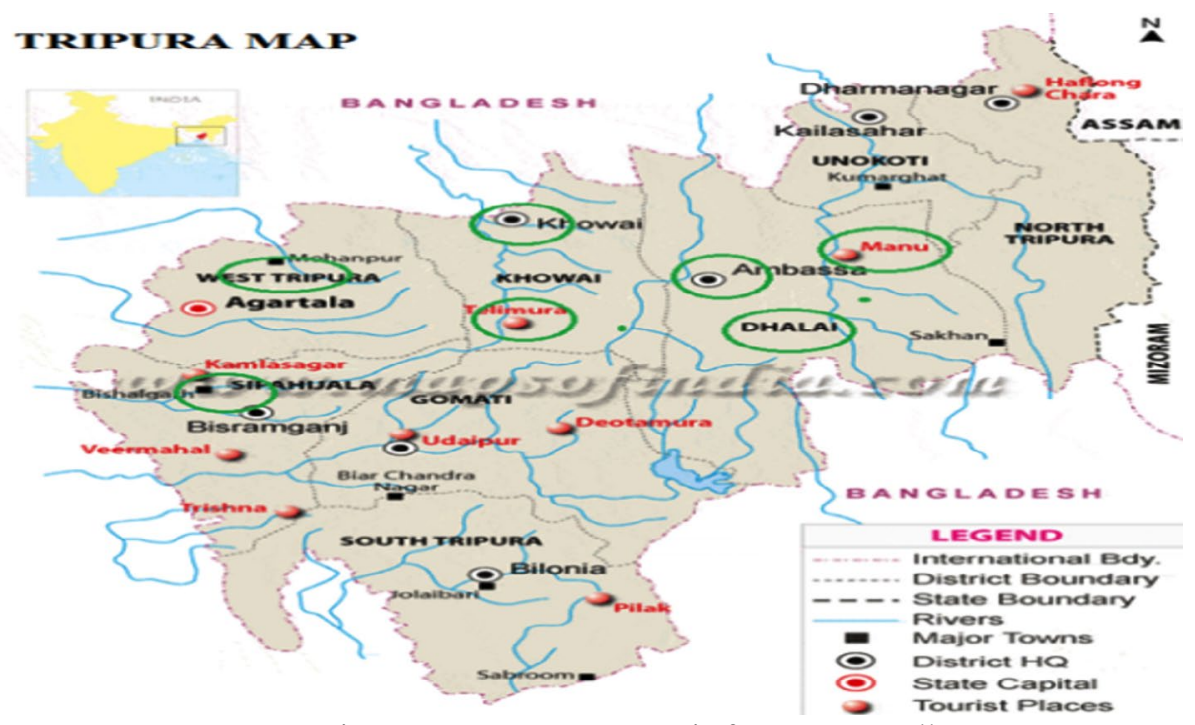

Fig. 1. Sample collection site (encircled with green colour) of Tripura, India. ${ }^{11}$ 
Table 1. List of wild edible minor fruits of Tripura, India considered for the study

\begin{tabular}{|c|c|c|c|c|c|c|c|}
\hline No. & $\begin{array}{l}\text { Botanical name } \\
*(I P N I) \& \text { family } \\
\text { name }\end{array}$ & $\begin{array}{l}\text { Voucher } \\
\text { specimen } \\
\text { number }\end{array}$ & Local name & $\begin{array}{l}\text { Time of } \\
\text { availability }\end{array}$ & Taste & Uses: folk medicines & Ref. \\
\hline 1 & $\begin{array}{l}\text { Garcinia gummi- } \\
\text { gutta (L.) N. } \\
\text { Robson; } \\
\text { Clusiaceae }\end{array}$ & $\begin{array}{l}\text { SB-28, } \\
\text { 23.06.2015, } \\
\text { Tablabari, } \\
\text { Khowai }\end{array}$ & $\begin{array}{l}\text { B-Kowagota } \\
\text { K-Kouk } \\
\text { R-Akouk }\end{array}$ & $\begin{array}{l}\text { May - } \\
\text { July }\end{array}$ & $\begin{array}{l}\text { Sour } \\
\text { and } \\
\text { sweet }\end{array}$ & $\begin{array}{l}\text { Raw fruits as juice, } \\
\text { pickles, use treatment } \\
\text { for Diarrhoea as folk } \\
\text { medicine. }\end{array}$ & {$[11]$} \\
\hline 2 & $\begin{array}{l}\text { Protium serratum } \\
\text { Engl.; } \\
\text { Burseraceae }\end{array}$ & $\begin{array}{l}\text { SB-21, } \\
\text { 12.06.2015, } \\
\text { Tablabari } \\
\text { Khowai }\end{array}$ & $\begin{array}{l}\text { B-Niyar } \\
\text { K-Thychrm } \\
\text { R-Thaichramm }\end{array}$ & $\begin{array}{l}\text { May - } \\
\text { July }\end{array}$ & Sour & $\begin{array}{l}\text { Fruits are used for } \\
\text { treatment of mouth } \\
\text { ulcer, fruits have } \\
\text { antioxidant properties }\end{array}$ & {$[11]$} \\
\hline 3 & $\begin{array}{l}\text { Stixis suaveolens } \\
\text { (Roxb.) Pierre.; } \\
\text { Capparaceae }\end{array}$ & $\begin{array}{l}\text { SB-22, } \\
\text { 4.06.2016, } \\
\text { Tablabari, } \\
\text { Khowai }\end{array}$ & $\begin{array}{l}\text { B- Madhabi } \\
\text { K- Majeelota } \\
\text { R-Mooni }\end{array}$ & $\begin{array}{l}\text { May - } \\
\text { July }\end{array}$ & $\begin{array}{l}\text { Taste } \\
\text { like } \\
\text { ripen } \\
\text { date } \\
\text { palm }\end{array}$ & $\begin{array}{l}\text { Fruits are used as } \\
\text { consumption, also use } \\
\text { folk medicine for heart } \\
\text { disease, asthma. }\end{array}$ & {$[11]$} \\
\hline 4 & $\begin{array}{l}\text { Flacourtia } \\
\text { jangomas } \\
\text { (Lour.) Raeusch } \\
\text { Salicaceae }\end{array}$ & $\begin{array}{l}\text { SB-64 } \\
23.8 .2016 \\
\text { Ajagartilla, } \\
\text { Khowai }\end{array}$ & $\begin{array}{l}\text { B-Tipafol / } \\
\text { Paniol } \\
\text { K- Tekroi } \\
\text { R- Tekrui }\end{array}$ & $\begin{array}{l}\text { July - } \\
\text { Nov }\end{array}$ & $\begin{array}{l}\text { Mild } \\
\text { sour } \\
\text { and } \\
\text { tangy } \\
\text { taste }\end{array}$ & $\begin{array}{l}\text { Consumed as raw and } \\
\text { cooked, salt-dried, jam, } \\
\text { marmalade, leaves and } \\
\text { fruits used against } \\
\text { diarrhea, Dried leaves } \\
\text { effectively for bronchitis. }\end{array}$ & $\begin{array}{l}\text { Present } \\
\text { study }\end{array}$ \\
\hline 5 & $\begin{array}{l}\text { Syzygium assami } \\
\text { cum (Biswas \& C. } \\
\text { S.Purkay.) } \\
\text { Raizada; } \\
\text { Myrtaceaeite }\end{array}$ & $\begin{array}{l}\text { SB-46, } \\
\text { 12.07.2016, } \\
\text { Tablabari, } \\
\text { Khowai }\end{array}$ & $\begin{array}{l}\text { B- } \\
\text { Khudikalajam } \\
\text { K-Jamuk } \\
\text { R-Jamuk }\end{array}$ & $\begin{array}{l}\text { May - } \\
\text { Sept }\end{array}$ & $\begin{array}{l}\text { Slightly } \\
\text { bitter } \\
\text { in taste } \\
\text { and } \\
\text { sweet }\end{array}$ & $\begin{array}{l}\text { For treating diabetes } \\
\text { (seeds) }\end{array}$ & {$[11]$} \\
\hline 6 & $\begin{array}{l}\text { Spondias dulcis } \\
\text { L. Anacardiaceae }\end{array}$ & $\begin{array}{l}\text { SB-66 } \\
20.6 .2016 \\
\text { Champah } \\
\text { ar, Khowai }\end{array}$ & $\begin{array}{l}\text { B-Amra } \\
\text { K-Thaitwi } \\
\text { R-Thaitu }\end{array}$ & $\begin{array}{l}\text { June - } \\
\text { Aug }\end{array}$ & $\begin{array}{l}\text { Sour in } \\
\text { Taste }\end{array}$ & $\begin{array}{l}\text { Consumed as raw, } \\
\text { Prepared pickle, } \\
\text { flavoring for sauces, } \\
\text { stews, Fruits has been } \\
\text { used as diuretic and } \\
\text { Febrifuge, bark is } \\
\text { astringent, dysentery } \\
\text { etc. }\end{array}$ & $\begin{array}{l}\text { Present } \\
\text { study }\end{array}$ \\
\hline 7 & $\begin{array}{l}\text { Artocarpus } \\
\text { lacuchaBuch.- } \\
\text { Ham } \\
\text { Moraceae }\end{array}$ & $\begin{array}{l}\text { SB-54 } \\
12.7 .2016 \\
\text { Tablabari, } \\
\text { North } \\
\text { Chebri }\end{array}$ & $\begin{array}{l}\text { B-Dowa } \\
\text { K-Dawa } \\
\text { R-Dua }\end{array}$ & $\begin{array}{l}\text { May- } \\
\text { July }\end{array}$ & $\begin{array}{l}\text { Slightly } \\
\text { sweets } \\
\text { sour }\end{array}$ & $\begin{array}{l}\text { As raw ripen fruits, } \\
\text { seeds consumed by } \\
\text { roasted, seeds have } \\
\text { medicinal properties }\end{array}$ & $\begin{array}{l}\text { Present } \\
\text { study }\end{array}$ \\
\hline 8 & $\begin{array}{l}\text { Ficus hispida L. } \\
\text { Moraceae }\end{array}$ & $\begin{array}{l}\text { SB-65 } \\
12.7 .2016 \\
\text { Tulashikh } \\
\text { ar, Khowai }\end{array}$ & $\begin{array}{l}\text { B- } \\
\text { Jagadamru } \\
\text { K-Khuichang } \\
\text { R-Khoichawng }\end{array}$ & $\begin{array}{l}\text { May- } \\
\text { July }\end{array}$ & $\begin{array}{l}\text { Slightly } \\
\text { sweet }\end{array}$ & $\begin{array}{l}\text { Consumed as raw, used } \\
\text { for Jaundice, edema, } \\
\text { anemia, leprosy, ulcers, } \\
\text { epitasis. }\end{array}$ & $\begin{array}{l}\text { Present } \\
\text { study }\end{array}$ \\
\hline 9 & $\begin{array}{l}\text { Citrus } \\
\text { macroptera } \\
\text { Montrouz.; } \\
\text { Rutaceae }\end{array}$ & $\begin{array}{l}\text { SB-34, } \\
\text { 10.10.2015, } \\
\text { Tulasikhar } \\
\text { h, Khowai }\end{array}$ & $\begin{array}{l}\text { B-Sathkora } \\
\text { K-Chatukora } \\
\text { R-Saataokra }\end{array}$ & $\begin{array}{l}\text { Sept- } \\
\text { Nov }\end{array}$ & Sour & $\begin{array}{l}\text { Fruits are eaten raw. } \\
\text { Peels of fruit used for } \\
\text { tenderization of meat, } \\
\text { treating gastritis, } \\
\text { kidney stone treatment. }\end{array}$ & [11] \\
\hline
\end{tabular}

*IPNI: International Plant Names Index, Local names: B-Bangla; K- Kakborak; R- Reang. 
districts of Tripura viz., Khowai, Dhalai, West Tripura and Sipahijala during different seasons in Feb-2018 and July-2019 and live specimens were collected (Table 1). One hundred (100) nos fruits per species were collected from 10 different plants. All the plant species selected for the present study were scientifically identified by the taxonomists, Prof. B.K. Datta, Department of Botany, Tripura University, Tripura, India and Dr. A. Kaur, The Energy and Resources Institute, NER Center, Guwahati, Assam, India.

\section{Bacterial strains}

Five bacterial strains viz. Escherichia coli (Gram-Ve, ATCC-2522), Pseudomonas aeruginosa (Gram-Ve, ATCC-27853), Klebsiella pneumoniae (Gram-Ve, ATCC-700603), Salmonella typhi (Gram -Ve, ATCC-14028), and Staphylococcus aureus (Gram +Ve, ATCC-25923) (Plate 1a \& b) were collected from the Institute of Jorhat Medical College and Hospital, Jorhat, Assam, India for the present study.
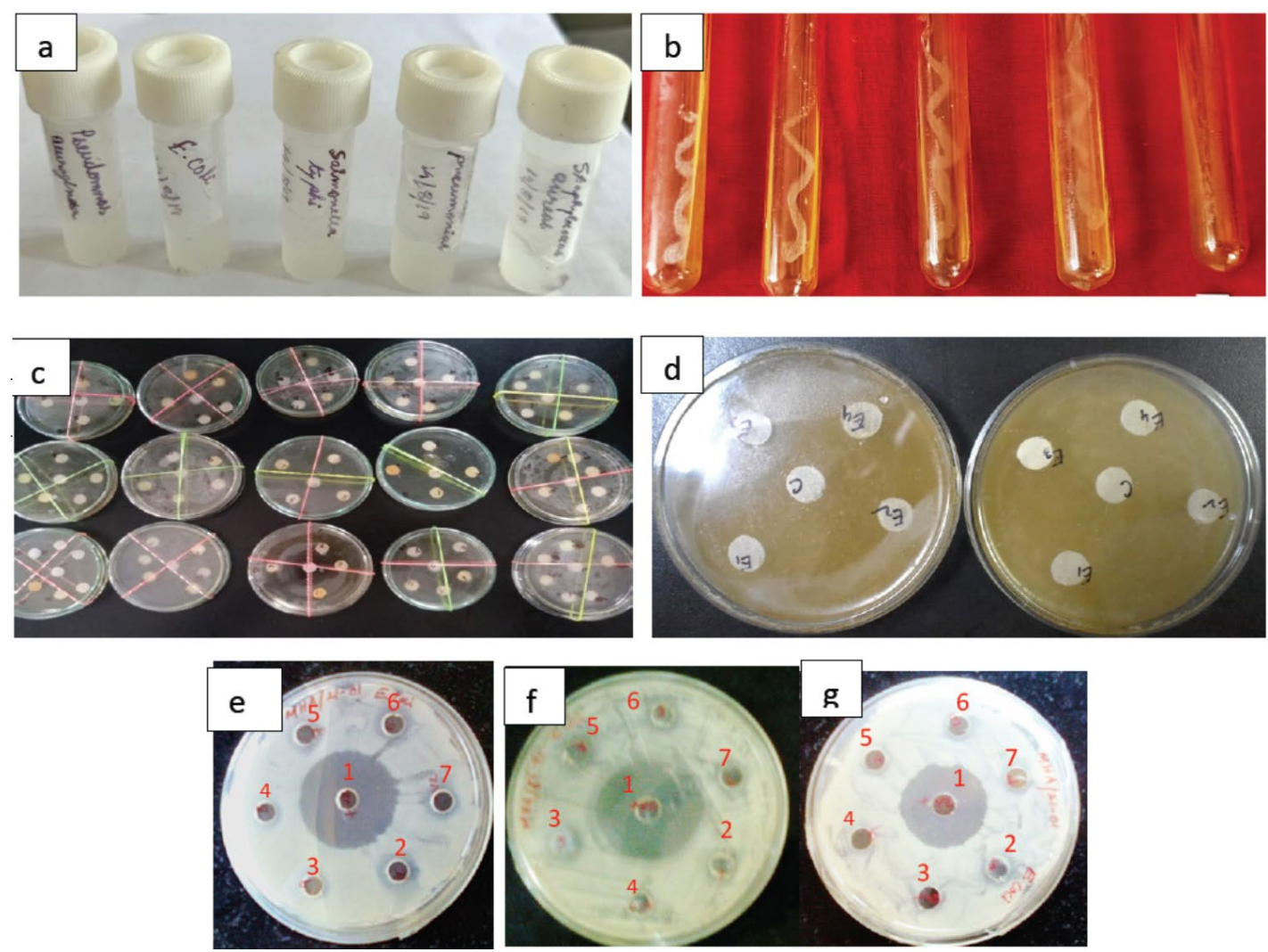

Plate 1(a-i). a. Microorganism in used in the study (L-R) :Pseudomonas auriginosa (ATCC27853), Eschercia coli (ATCC-2522), Salmonella typhi (ATCC-14028), Klebsiella pneumoniae (ATCC-700603), Staphylococcus aureus (ATCC25923), b. Pure culture of (L-R): Pseudomonas auriginosa (ATCC-27853), Eschercia coli (ATCC-2522), Salmonella typhi (ATCC-14028), Klebsiella pneumoniae (ATCC-700603), Staphylococcus aureus (ATCC-25923), c. General view of in vitro assay on antibacterial assay of fruit extract against the targeted pathogens, $d$. Closer view of in vitro assay on antibacterial assay of fruit extract against the targeted pathogens, e. Inhibition of growth of $E$. coli by different plant extract (1: G. gummi-gutta at $100 \mathrm{mg} / \mathrm{ml}$, 2. S. suaveolens at $100 \mathrm{mg} / \mathrm{ml}, 3$. G. gummi-gutta at 25 $\mathrm{mg} / \mathrm{ml}$, 4. Control, 5. S. suaveolens at $25 \mathrm{mg} / \mathrm{ml}, 6$. G. gummi-gutta at $50 \mathrm{mg} / \mathrm{ml}, 7$. G. gummi-gutta at $50 \mathrm{mg} / \mathrm{ml}$ ), f. Inhibition of growth of S. typhi by different plant extract (1. G. gummi-gutta at $100 \mathrm{mg} / \mathrm{ml}$, 2. S. assamicum at $100 \mathrm{mg} / \mathrm{ml}, 3$. G. gummi-gutta at $75 \mathrm{mg} / \mathrm{ml}$, 4. Control, 5. S. assamicum at $25 \mathrm{mg} / \mathrm{ml}, 6$. A. lackocha at $75 \mathrm{mg} / \mathrm{ml}$, 7. A. lackocha at $50 \mathrm{mg} / \mathrm{ml}$, g. Inhibition of growth of $S$. aureus by different plant extract (1. G. gummi-gutta at $100 \mathrm{mg} / \mathrm{ml}, 2$. S. suaveolens at $100 \mathrm{mg} / \mathrm{ml}, 3$. P. serratum at $100 \mathrm{mg} / \mathrm{ml}, 4$. Control, 5. S. dulcis at $100 \mathrm{mg} / \mathrm{ml}, 6$. F. jangomas at $100 \mathrm{mg} / \mathrm{ml}, 7$. F. hispida at $100 \mathrm{mg} / \mathrm{ml}$ 
Biswas et al. | J Pure Appl Microbiol | 15(4):1976-1986 | December 2021 | https://doi.org/10.22207/JPAM.15.4.19

Table 2. Antibacterial activity of ethanol extracts of wild fruits against five human bacterial pathogens

\begin{tabular}{|c|c|c|c|c|c|c|}
\hline \multirow[t]{2}{*}{ Plant name } & \multirow{2}{*}{$\begin{array}{l}\text { Concen. } \\
\text { (mg/mL) }\end{array}$} & \multicolumn{5}{|c|}{ Inhibition zone $(\mathrm{mm})^{*}$} \\
\hline & & E. coli & S. aureus & P. auriginosa & K. pneumoniae & S. typhi \\
\hline \multirow[t]{5}{*}{ G. gummi-gutta } & 25 & $7.0 \pm 1.05$ & $5.0 \pm 1.12$ & $5.5 \pm 0.98$ & $6.5 \pm 1.21$ & $4.5 \pm 1.59$ \\
\hline & 50 & $16.5 \pm 1.10$ & $13.5 \pm 0.99$ & $13.5 \pm 1.92$ & $11.0 \pm 1.32$ & $10.0 \pm 1.78$ \\
\hline & 75 & $23.4 \pm 1.23$ & $21.6 \pm 0.87$ & $20.5 \pm 1.26$ & $19.0 \pm 1.44$ & $17.5 \pm 1.40$ \\
\hline & 100 & $35.0 \pm 1.06$ & $32.0 \pm 1.12$ & $33.5 \pm 1.62$ & $31.5 \pm 1.52$ & $32.5 \pm 1.38$ \\
\hline & 25 & - & - & $4.0 \pm 1.71$ & $3.5 \pm 1.39$ & - \\
\hline \multirow[t]{3}{*}{ P. serratum } & 50 & - & - & $7.5 \pm 1.29$ & $7.0 \pm 1.83$ & - \\
\hline & 75 & - & - & $13.0 \pm 0.78$ & $12.0 \pm 1.52$ & - \\
\hline & 100 & - & - & $21.0 \pm 1.93$ & $18.0 \pm 1.84$ & - \\
\hline \multirow[t]{6}{*}{ S. suaveolens } & 25 & $0.0 \pm 1.00$ & $0.0 \pm 1.54$ & $3.0 \pm 0.91$ & $0.0 \pm 1.96$ & - \\
\hline & 50 & $3.0 \pm 1.21$ & $3.0 \pm 1.62$ & $7.5 \pm 0.99$ & $0.0 \pm 1.20$ & - \\
\hline & 75 & $6.5 \pm 1.09$ & $5.0 \pm 1.23$ & $15.0 \pm 1.74$ & $5.0 \pm 1.36$ & - \\
\hline & 100 & $10.0 \pm 1.21$ & $9.0 \pm 1.41$ & $21.0 \pm 1.65$ & $9.0 \pm 1.94$ & \\
\hline & 25 & - & $0.0 \pm 1.22$ & $0.0 \pm 1.65$ & $0.0 \pm 0.79$ & - \\
\hline & 50 & - & $3.0 \pm 1.32$ & $4.0 \pm 1.72$ & $0.0 \pm 0.82$ & - \\
\hline \multirow[t]{4}{*}{ F. jangomas } & 75 & - & $6.5 \pm 1.07$ & $6.5 \pm 1 / 25$ & $4.5 \pm 1.64$ & - \\
\hline & 100 & - & $11.0 \pm 1.17$ & $10.5 \pm 1.71$ & $8.5 \pm 1.72$ & \\
\hline & 25 & $5.5 \pm 0.74$ & $4.0 \pm 1.25$ & - & - & $4.5 \pm 1.28$ \\
\hline & 50 & $9.0 \pm 1.72$ & $7.5 \pm 1.42$ & - & - & $7.5 \pm 1.42$ \\
\hline \multirow[t]{4}{*}{ S. assamicum } & 75 & $17.5 \pm 1.48$ & $13.5 \pm 1.52$ & - & - & $12.0 \pm 1.63$ \\
\hline & 100 & $32.5 \pm 1.30$ & $23.0 \pm 1.33$ & - & - & $19.0 \pm 1.72$ \\
\hline & 25 & - & - & $0.0 \pm 1.77$ & - & - \\
\hline & 50 & - & - & $0.0 \pm 1.62$ & - & - \\
\hline \multirow[t]{4}{*}{ S. dulcis } & 75 & - & - & $3.5 \pm 1.52$ & - & - \\
\hline & 100 & - & - & $9.0 \pm 1.64$ & & - \\
\hline & 25 & $6.5 \pm 1.24$ & $4.5 \pm 1.71$ & $9.5 \pm 1.76$ & $0.0 \pm 0.56$ & $7.50 \pm 1.94$ \\
\hline & 50 & $12.5 \pm 1.73$ & $9.5 \pm 1.10$ & $15.5 \pm 1.82$ & $4.5 \pm 1.62$ & $14.0 \pm 1.37$ \\
\hline \multirow[t]{4}{*}{ A. lackocha } & 75 & $19.0 \pm 1.86$ & $15.5 \pm 1.26$ & $21.0 \pm 1.43$ & $9.5 \pm 1.80$ & $19.5 \pm 0.81$ \\
\hline & 100 & $33.5 \pm 1.52$ & $24.0 \pm 1.62$ & $34.5 \pm 1 / 23$ & $15.0 \pm 1.88$ & $32.0 \pm 1.82$ \\
\hline & 25 & - & - & $3.0 \pm 1.49$ & - & - \\
\hline & 50 & - & - & $6.5 \pm 1.71$ & - & - \\
\hline \multirow[t]{3}{*}{ F. hispida } & 75 & - & - & $12.5 \pm 1.64$ & - & - \\
\hline & 100 & - & - & $18.0 \pm 1.93$ & & - \\
\hline & 25 & - & - & - & - & - \\
\hline \multirow[t]{3}{*}{ C. macroptera } & 50 & - & - & - & - & - \\
\hline & 75 & - & - & - & - & - \\
\hline & 100 & & - & - & & - \\
\hline
\end{tabular}

*Data are mean of five replicates; ' ${ }^{\prime}:$ : No inhibition was observation at the tested concentration.

Preparation of Extracts

The wild fruits samples were collected and washed independently in two fold sterile distilled water and freeze dried for 72 hours, followed by drying in hot air oven (Labotech Solutions, India) at $50{ }^{\circ} \mathrm{C}$ consecutively for four days. The dried fruits were ground to a fine powder and stored completely dried in a cleaned dry glass holder and protected from the microbial contaminations. One gram of the powder (fine) was transferred into each of the four sterile Falcon tubes (cap. $15 \mathrm{~mL}$ ) and added $10 \mathrm{~mL}$ of sterile water and ethanol(absolute) respectively. Extraction was prepared by continuous vigorous shaking and sonicating (4X15 $\mathrm{min}$ in a $24 \mathrm{~h}$ period) in sonicator water bath. On fourth day, tubes were centrifuged for $15 \mathrm{~min}$ at $2058 \mathrm{~g}$ and the supernatant was transferred to $1 \mathrm{~mL}$ aliquots to various Eppendorf containers of limit $1.5 \mathrm{~mL}$. After the evaporation of the solvent, the dried residues of $1 \mathrm{~mL}$ extract 
were re-dissolved in $200 \mu \mathrm{L}$ DMSO for the ethanol extracts. The sediments were refrigerated at $4^{\circ} \mathrm{C}$ until further use.

\section{Preparation of inoculum}

Inoculum of the bacterial strains were prepared by moving a loopful of cells from the way of life to test containers of Mueller-Hinton Broth (MHB) and were brooded without disturbance for $24 \mathrm{hrs}$ at $37^{\circ} \mathrm{C}$. The way of life was additionally diluted with new MHB to get optical densities of $2 \times 10^{6} \mathrm{cfu} / \mathrm{mL}$.

\section{Antibacterial activity of fruits extract}

The antibacterial activity of each fruit sample was determined using the disk difusion method with need based modification. ${ }^{16}$. The disk diffusion method was performed using MuellerHinton Agar (MHA). The ethanol extracted (100 $\mathrm{mg}$ ) was fragmented up in $2 \mathrm{~mL}$ of dimethyl sulfoxide and sanitized through a film channel $(0.22 \mu \mathrm{m})$ and tested at four (4) concentrations. viz., $100,75,50$, and $25 \mathrm{mg} / \mathrm{mL}$ by pouring $5 \mu \mathrm{L}$ over the $6-\mathrm{mm}$ distance across of disinfected channel paper plates. At that point, $10-15 \mathrm{~mL}$ of agar medium was filled disinfected Petri-dishes and represented setting for 15 minutes, followed by the expansion of $100 \mu \mathrm{L}$ of bacterial culture on the plate's head, spread with sterile L-circle and permitted to dry for few moments. Finally, the sterile channel paper circle stacked with various groupings of organic products removed was set on the head of MHA plates and represented brooding for 24 hours. The antibacterial action was assessed by estimating the width of the inhibitory zone for the test microorganisms. The inhibition zone developed due to the action of extract were measured by subtracting disk diameter (6-mm). The potential extracts were chosen based on the highest inhibition zone developed.

Determination of minimum inhibitory concentration (MIC)

MIC of the fruits extracts was measured by following the tube dilution technique. ${ }^{17}$ Twofold dilution of the fruits extracts $(25,50,75$ and $100 \mathrm{mg} / \mathrm{mL}$ ) were set up in tubes containing nutrient broth. Equal volume of extract and nutrient broth were mixed in each test tube. After that, $0.1 \mathrm{~mL}$ of adjusted inoculum of the bacteria $\left(1 \times 10^{8} \mathrm{cfu} / \mathrm{mL}\right)$ was added to each tube. All plates were incubated for 24 hours at $37^{\circ} \mathrm{C}$. Two control tubes were maintained, one for positive control containing anti-toxins, and the other was a negative control containing bacterial inoculum, physiological saline and stock medium. Antibiotic disk of ciprofloxicin (1 $\mu \mathrm{g}$ ) was used for E coli, P. aeruginosa, K. pneumoniae, S. aureus and azithromycin for $S$. typhi as reference antibiotic. Turbidity was adjusted to. $0.5 \mathrm{McF}$. and speeded on plates.

\section{Determination of minimum bactericidal concentration (MBC)}

MBC was determined by sub-culturing the MIC test dilutions followed by Abdullah and Elsharkawy. ${ }^{17}$ For this $50 \mu \mathrm{L}$ of incubated test tubes from the MIC, an assay was pipette carefully and transferred to sterile nutrient agar plates. Plates were then incubated overnight at $37^{\circ} \mathrm{C}$ and were observed for any visible growth. The lowest MIC concentration that exhibited no visible bacterial growth on the agar plate was taken as MBC.

\section{Statistical analysis}

The results obtained from the experiments of the present study were expressed as mean \pm SD. Data recorded from dose-response experiments were represented as the percentage of inhibition and analyzed with Prism TM (Graph Pad Prism 5.0 Software Inc; San Diego, CA). The MIC50 for each growth condition was estimated by fitting the data to a non-linear least- squares sigmoid regression curve.

\section{RESULTS}

\section{Ethnobotanical documentation}

Ethnobotanical uses of nine (9) plant species belonging to eight (8) families (Rutaceae, Burseraceae, Capparaceae, Myrtaceae, Cluceae, Salicaceae, Moraceae, Anacardiaceae) were recorded from tribal areas of Tripura (Table 1). Among the nine (9) wild fruits species, five (5) fruits, viz., G .gummi-gutta, P. serratum, S. assamicum and $C$. macroptera were reported in our earlier investigation ${ }^{11}$ and the four (4) fruits: $F$. jangomas, S. dulcis, A. lacucha, and F. hispida are documented in the present study (Table 1). The table provides information on the botanical name, family, local name (Bangali, Kokbork, Reang), time of availability, taste and use in folk medicine. Tribal people use these wild fruit plants for a different therapeutic purpose like treating kidney stones, antioxidant property, heart diseases, asthma, diabetes, diarrhea, bronchitis, jaundice, edema, 
Table 3. MIC and MBC value of selected fruits extracts against five bacterial strains

\begin{tabular}{|c|c|c|c|c|c|c|c|c|c|c|c|}
\hline \multirow[t]{3}{*}{ Plant name } & \multirow{3}{*}{$\begin{array}{l}\text { Concen. } \\
\text { (mg/ml) }\end{array}$} & \multicolumn{10}{|c|}{ Bacterial pathogens } \\
\hline & & \multicolumn{2}{|c|}{ E. coli } & \multicolumn{2}{|c|}{ S. aureus } & \multicolumn{2}{|c|}{ P. aeruginosa } & \multicolumn{2}{|c|}{ K. pneumoniae } & \multicolumn{2}{|c|}{ S. typhi } \\
\hline & & MIC & $\mathrm{MBC}$ & MIC & $\mathrm{MBC}$ & MIC & $\mathrm{MBC}$ & MIC & $\mathrm{MBC}$ & MIC & $\mathrm{MBC}$ \\
\hline & 25 & + & + & + & + & + & + & + & + & + & + \\
\hline G. gummi- & 50 & - & + & - & + & - & + & - & + & - & + \\
\hline \multirow[t]{3}{*}{ gutta } & 75 & - & - & - & - & - & - & - & - & - & - \\
\hline & 100 & - & - & - & - & - & - & - & - & - & - \\
\hline & 25 & 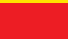 & & 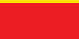 & 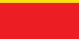 & + & + & + & + & 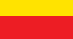 & \\
\hline \multirow[t]{4}{*}{ P. serratum } & 50 & & & & 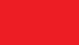 & + & + & + & + & & \\
\hline & 75 & & & & & - & - & - & + & & \\
\hline & 100 & & & & & - & - & - & - & & \\
\hline & 25 & + & + & + & + & + & + & + & + & & \\
\hline \multirow[t]{4}{*}{ S. suaveolens } & 50 & + & + & + & + & - & - & + & + & & \\
\hline & 75 & - & + & + & + & - & - & - & + & & \\
\hline & 100 & - & - & - & - & - & - & - & - & & \\
\hline & 25 & . & - & + & + & + & + & + & + & & \\
\hline \multirow[t]{4}{*}{ F. jangomas } & 50 & & & + & + & + & + & + & + & & \\
\hline & 75 & & & - & + & - & + & - & + & & \\
\hline & 100 & . & & - & - & - & - & - & - & & \\
\hline & 25 & - & - & - & + & & 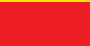 & & & - & + \\
\hline \multirow[t]{4}{*}{ S. assamicum } & 50 & - & - & - & - & & 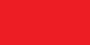 & & & - & - \\
\hline & 75 & - & - & - & - & & & & & - & - \\
\hline & 100 & - & - & - & - & . & 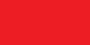 & & & - & - \\
\hline & 25 & 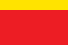 & 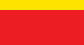 & 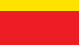 & 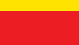 & + & + & & & & \\
\hline \multirow[t]{4}{*}{ S. dulcis } & 50 & & & & & + & + & & & & \\
\hline & 75 & & & & & + & + & & & & \\
\hline & 100 & & & & & - & - & & & & \\
\hline & 25 & - & - & - & + & - & - & + & + & - & - \\
\hline \multirow[t]{4}{*}{ A.lackocha } & 50 & - & - & - & - & - & - & - & + & - & - \\
\hline & 75 & - & - & - & - & - & - & - & - & - & - \\
\hline & 100 & - & - & - & - & - & - & - & - & - & - \\
\hline & 25 & & & & & - & + & & & & \\
\hline \multirow[t]{3}{*}{ F. hispida } & 50 & & & & & - & - & & & & \\
\hline & 75 & & & & & - & - & & & & \\
\hline & 100 & & & & & - & - & & & & \\
\hline
\end{tabular}

Red color means: MIC was MBC were not performed as these concentrations do not have any inhibitory effect (Please refer Table 2) Yellow color means; MIC and MBC were analyzed as at these concentrations the botanicals showed inhibitory effect (Please refer Table 2).

anemia, leprosy, ulcers, epitasis, dysentery, etc. All these plants and fruits are found to have high popularity among the tribes due to their value added efficiency and awareness by the native tribes for their everyday use as an herbal medicine. But the ethnobotanical data on the bioprospecting of traditional plants for medicinal uses is always a controversy owing to a different report by different workers. Soejarto et al. ${ }^{18}$ reported that less than $15 \%$ of plant species traditionally used for medicinal purpose is subjected to clinical trials. Still, the advantages of lying in plant selection based on traditional knowledge can't be ignored. This is because it guides us to target the parts to be used for testing against a disease, avoiding wastage of time and resources in unnecessary testing of inactive plant parts. It also guides us in the steps of processing the materials and the route of administration. Research on natural resources under ethnobotanical guidance could generate 
more information for the more significant benefit of human beings and the associated ecosystem. But, the traditional knowledge and practice of apply traditional medicine are disappearing slowly that call the urged need of ethnobotanists to create mass awareness and capacity building for the conservation of the traditional plant species. Saslis-Lagoudakis et al. ${ }^{19}$ reported that conventional knowledge that enhances health throughout the world is crucial consideration in preventing worsening health. New research initiatives demonstrate the revival of interest in the subject.

\section{Antibacterial activity}

Extract prepared from the wild fruit was tested for antibacterial activity in dilution broth assay against the five bacterial microorganisms, viz., E. coli, P. aeruginosa, K. pneumoniae, S. typhi, and $S$. aureus (Plate $1 \mathrm{c}-\mathrm{g}$ ). The antibacterial assay was done by disk diffusion technique at four (4) concentrations viz., $100,75,50$ and $25 \mathrm{mg} / \mathrm{mL}$. All the wild fruits extract except $C$. macroptera, showed antibacterial activity against the bacterial strains and with highest zone of inhibition (35.0 $\mathrm{mm}$ ) against $E$. coli at $100 \mathrm{mg} / \mathrm{ml}$ concentration of ethahnol extract of G. gummi-gutta (Table 2). This was followed by a zone of inhibition of 34.50 $\mathrm{mm}$ by ethanol extract of $A$. lakoocha against $P$. aurigenosa. Interestingly, out of all the fruit extracts only G. gummi-gutta and A. lakoocha showed their antibacterial activities against all the bacterial pathogen under this study. Therefore, these plants may be suitable candidates for discovering board-spectrum antibiotics against the tested bacteria. G. gummi-gutta causes zone inhibition of $33.5 \mathrm{~mm}, 32.5 \mathrm{~mm}, 32.00$ and 31.5 $\mathrm{mm}$ against $P$. auriginosa, $S$. typhi, $S$. aureus and $K$. pneumonia respectively at $100 \mathrm{mg} / \mathrm{ml}$ of concentration and with decrease of concentration the zone of inhibitions was found to decreases. In case of fruit extract of $A$. lakoocha, the zone of inhibition of $33.5 \mathrm{~mm}, 32.0 \mathrm{~mm}, 24.0 \mathrm{~mm}$ and $15.0 \mathrm{~mm}$ was recorded for E. coli, S. typhi, S. aureus and $K$. pneumonia respectively at 100 $\mathrm{mg} / \mathrm{ml}$ of concentration. For the fruit extract of $P$. serratum no antibacterial activity was observed against E. coli, S. aureus, and S. typhi. Similarly, no antibacterial activity of $S$. suaveolens was observed against S. typhi. On the other hand S. dulcis and $F$. hispida showed antibacterial activity against only
P. auriginosa. Similarly, F. jangomas was found to have antibacterial activity against $S$. aureus, $P$. auriginos $a$ and $K$. pneumonia with varying degree of zone of inhibition at different concentration but no inhibitory effect of was found against $E$. coli and $S$. typhi. Fruit extracts of $S$. suaveolens and $F$. jangomas at concentration of 25 and $50 \mathrm{mg} / \mathrm{ml}$ could not able to inhibit the growth of $K$. pnemonie but at higher concentration i.e., 50 and $100 \mathrm{mg} /$ $\mathrm{ml}$ it could able to inhibit the growth significantly. Several scientists have reported the composition, antimicrobial, antifungal and antioxidant activities of essential oils, especially from different fruits of the citrus genus..$^{20-22}$ It has been recognized for centuries that essential oils possessed antimicrobial property. Citrus oils have the GRAS status for food and drug applications possessing the inhibitory effects against a range of both gram positive and gram negative bacteria both as in the form of direct oil and in vapor form. ${ }^{23}$ Antimicrobial activities of both the fixed and essential oils were also evaluated earlier against different pathogenic bacterial strains following disk diffusion method.

The zones of inhibition of microbial growth are expressed a function of antimicrobial activity of the extracts. ${ }^{24}$ Data presented in Table 3 showed that $S$. suaveolen may be a potential source of drug to fight against all the tested organism in the study except $S$. typhi. Earlier, Saklani et al. ${ }^{25}$ studied the anti-bacterial activity of fruit extract of Rubus ellipticus and reported significant inhibitory effect against $E$. coli, which is practically identical to the current investigations. Correspondingly, Babahmad et al. ${ }^{26}$ revealed the impact of inhibitory action of numerous botanicals against gram-positive and gram-negative microscopic organisms with shifting degrees of hindrance zone, which are similar with the result of the current examination. In inhibition zone of $5 \pm 1.10$ to $20 \pm 0.31 \mathrm{~mm}$ was reported by Qadir et al. ${ }^{27}$ for seed extract of Anamirta cocculus against $P$. vulgaris, S. aureus, E. coli, K. pneumonia and S. typhi.

Eight plant removes at four novel centers $(25,50,75$ and $100 \mathrm{mg} / \mathrm{mL})$ were attempted against five particular bacterial microorganisms and results are summarized in Table 3 . The MIC and $\mathrm{MBC}$ assessments of bacterial strains were found to the extent of $50-100 \mathrm{mg} / \mathrm{mL}$ and $75-$ $100 \mathrm{mg} / \mathrm{mL}$ respectively. The MIC and MBC value 
for G. gummi-gutta was recorded to the extent of $75-100 \mathrm{mg} / \mathrm{mL}$, against all the five bacterial strains. However, the value was $100 \mathrm{mg} / \mathrm{mL}$ for $S$. suaveolens against E. coli, S. aureus, P. aeruginosa and $K$. pneumoniae. Lowest MIC and MBC values of $25 \mathrm{mg} / \mathrm{mL}$ were recorded for $S$. assamicum, against E. coli and A. lacucha against E. coli, S. aureus, $P$. aeruginosa, and $S$. typhi.

Most of the test extracts inhibited the growth of the pathogens and the present studies are in agreement with the earlier worker ${ }^{28,29}$ who reported greater antibacterial activity of Indian Medicinal plants on Gram positive and Gram negative bacteria. But the efficacy was more in Gram positive bacteria then the Gram negative bacteria, which may be due to the nature of cell structure. ${ }^{30}$ Kitzberger et al. ${ }^{31}$ defined MIC as inhibition of microbial growth after 24 hours of incubation when exposed to the lowest concentration of the plant extract and the minimum amount of plant extract that completely kill the respective microorganism after 24 hours of incubation on the freshly inoculated agar plates is called MBC. The lower extent of MIC and MBC regard suggests a different degree of antimicrobial development. The MIC and MBC value recorded in the current examination is higher than the assessment of wild berry natural item species, which was reported by Radovanovie et al. ${ }^{32}$ who got the value to the extent of 15.6 to $500 \mathrm{ug} / \mathrm{ml}$ against $S$. aureus. In another assessment by Islary et al. ${ }^{33}$ reported an $\mathrm{MBC}$ assessment of $15 \mathrm{mg} / \mathrm{mL}$ for fruit extract of Aporosa dioica against $S$. aureus and $P$. vulgaris and $\mathrm{MBC}$ assessment of $<30 \mathrm{mg} /$ $\mathrm{mL}$ was recorded for fruit extract of Antidesma bunius against all the four targeted strains.

\section{DISCUSSION}

In this research, out of nine (9) distinctive wild edible fruits species, two (2) viz., Garcinia gummi-gutta (L.) N. Robson; and Artocarpus lacucha Buch.-Ham, were discovered to be successful in stifling the development of the apparent multitude of bacterial microorganisms viz., E. coli, S. aureus, P. aeruginosa, K. pneumonia and S. typhi at a convergence of $75-100 \mathrm{mg} /$ $\mathrm{mL}$. We found the most minimal MIC and MBC estimations of $25 \mathrm{mg} / \mathrm{ml}$ were recorded for Syzygium assamicum (Biswas \& C. S. Purkay.) Raizada; against E. coli and Artocarpus lacucha
Buch.-Ham against E. coli, S. aureus, P. aeruginosa, and $S$. typhi showing the concrete antibacterial exercises. Our exercise has detailed four wild, edible fruits their society medication utilizes where included Flacourtia jangomas (Lour.) Raeusch, Spondias dulcis L., Artocarpus lacucha Buch.-Ham and Ficus hispida L., and five wild fruits sample have been reported ethnobotanical information in our past investigation. From the current examination, antibacterial exercises give a premise to tranquilize revelation from the indigenous wild eatable fruits devoured by the ancestral network of the North-Eastern province of India where especially, Tripura. Further exploration of the phytochemistry and pharmacological property of the wild consumable organic products must be done; investigating bioactive mixes and their activity method with the target site should also be examined.

\section{CONCLUSION}

The underutilized wild fruits are not used for commercial purpose due to lack of proper scientific study and documentation, although have high nutritional values. In light of this investigation, it is evident that further studies to find new, unconventional underutilized fruits from the wild is an urgent necessity. Which will enrich the fruits basket of the different states of India and it is hoped that popularization of these fruits for the benefit of the rest of the communities will gain momentum. We believe that our findings will open a new chapter for commercialization of those wild minor fruits for both cultivation and the mass uses to all communities. Further, this study paves the way of using the underutilized wild fruits of North Eastern region of India as a potential source of antipathogenic activity of human pathogen. Further details study may help in identifying the bioactive compound of industrial importance.

\section{ACKNOWLEDGMENTS}

We would like to express our heartfelt thanks to U. Paul A. Kumari, Bishal Saikia, P. Borgohain and G. Phookan for providing assistance during the experimentations. We would like to thank the Assam Agricultural University $(A A U)$, Jorhat, Assam, India for providing the facilities for experimentation. 


\section{CONFLICT OF INTEREST}

The authors declare that there is no conflict of interest.

\section{AUTHORS' CONTRIBUTION}

All authors listed have made a substantial, direct and intellectual contribution to the work, and approved it for publication.

\section{FUNDING}

None.

\section{DATA AVAILABILITY}

All datasets generated or analyzed during this study are included in the manuscript

\section{ETHICS STATEMENT}

Not applicable.

\section{REFERENCES}

1. Gombart AF, Pierre A, Maggini S. A review of micronutrients and the immune system working in harmony to reduce the risk of infection. Nutr. 2020;12(1):236. doi: 10.3390/nu12010236

2. Li Y, Zhang JJ Pingxu D, et al. Bio-activities and Health Benefits of wild fruits. Int J Mol Sci. 2016;17(8):1258. doi: 10.3390/ijms17081258

3. Brandi I, Fabbretti A, Teana AZ, et al. Specific, efficient, and selective inhibition of Prokaryotic translation initiation by a novel peptide antibiotic. Proc Natl Acad Sci USA. 2006;103(1):39-44. doi: 10.1073/ pnas. 0507740102

4. Mahammad CJ. Anti-microbial Activity of Phyllanthus emblica. J Biol Innov. 2016;5:979-984.

5. Tulecke W, Nickell LG. Production of large amount of plant tissue by submerged culture. Sci. 1959;130(3379):863864. doi: 10.1126/science.130.3379.863

6. Bhakuni DS, Dhar ML, Dhar MM, Dhawan BN, Mehrotra BN. Screening of Indian plants for biological activity. Part II. Ind J Exp Biol. 1969;7:250-262.

7. Bhakuni DS, Dhar ML, Dhar MM, Dhawan BN, Gupta B, Srimali RC. Screening of Indian plants for Biological activity. Part III. Ind J Exp Biol. 1971;9:91-102.

8. Dhar AL, Dhar MM, Dhawan BN, Mehrotra BN, Ray C. Screening of Indian Plants for biological activity. Part I. Indian J Exp Biol. 1968;6(4):232-247.

9. Farnsworth NR. Biological and Phyto-Chemical Screening of plants. J Pharm Sci. 1966;55(3):225-276. doi: 10.1002/jps.2600550302

10. Nath PC, Boruah S. Antimicrobial activity ethanolic and Methanolic Extract of Artocarpus lakoocha Wall. Ex Roxb. (Moraceae) against five different oral bacterial strains. Int J Curr Microbiol App Sci. 2019;8(3):13211325. doi: 10.20546/ijcmas.2019.803.156

11. Biswas SC, Majumder M, Das S, Misra TK. Diversity of wild edible minor fruits used by the ethnic communities of Tripura, India. Ind J Trad Knowl.
2018;17(2):282-289.

12. Edeoga HO, Okwu DE, Mbaebie BO. Phyto-chemical Constituents of some Nigerian medicinal plants. Afr J Biotech. 2005;4(7):685-688. doi: 10.5897/ AJB2005.000-3127

13. Reddy BK, Balaji M, Reddy UP, Sailaja G, Vaidyanath K, Narasimaha G. Anti-feedent and anti-microbial activity of Tylophora indica. Afr J Biochem Res. 2009;3(12):393397.

14. Savoia, D. Plant-derived antimicrobial compounds: alternatives to antibiotics. Fut Microbiol. 2012;7(8):979990. doi: $10.2217 / \mathrm{fmb} .12 .68$

15. Singh SN, Moses A, David A. Antimicrobial Activity of Emblica officinalis extracts against selected bacterials pathogens. Int J Basic App Res. 2019;9:325-330.

16. Jorgensen $P$, Edgington NP, Schneider BL, Rupes I, Tyers $M$, Futcher $B$. The Size of nucleus increases as yeast cells grow. Mol Biol Cell. 2007;18(9):3523-3532. doi: 10.1091/mbc.e06-10-0973

17. Abdallah EM, Elsharkawy ER. Antibacterial Activity of Ethyl Acetate Extract of Platycladus orientalis against Staphylococcus saprophyticus. J Pure Appl Microbiol. 2019;13(2):1063-1068. doi: 10.22207/JPAM.13.2.44

18. Soejarto DD, Fong H, Tan GT, et al. Ethnobotany/ ethnopharmacology and mass bio-prospecting: Issues in intellectual property and benefit sharing. J Ethnopharmacol. 2005;100(1-2):15-22. doi: 10.1016/j. jep.2005.05.031

19. Saslis-Lagoudakis $\mathrm{CH}$, Savolainen V, Williamson $E M$, et al. Phylogenies reveal predictive power of traditional medicine in bio-prospecting. Proc Natl Acad Sci USA. 2012;109:15835-15840. doi: 10.1073/ pnas.1202242109

20. Moure A, Gullon P, Dominguez H, Parajo JC. Advances in the manufacture, purification and applications of xylooligosaccharide as food additives and nutraceuticals. Proc Biochem. 2006;41(9):1913-1923. doi: 10.1016/j. procbio.2006.05.011

21. Mitchell JD, Daly DC. A revision of Spondias L. (Anacardiaceae) in the neotropics. Phyto Keys. 2015;55:1-92.

22. Merveille TO, Denis $\mathrm{Z}$, Abdel NJ, et al. Antimicrobial activities of some medicinal plants against multiresistant microorganism causing urogenital tract infection in Cameroon. J Dis Med Plants. 2017;3(2):3341.

23. Fisher K, Phillips C. Potential antimicrobial uses of essential oils in food: is citrus the answer? Trends Food Sci Technol. 2008;19(3):156-164. doi: 10.1016/j. tifs.2007.11.006

24. Zofou D, Shu GL, Foba-Tendo J, Tabouguia MO, Assob $\mathrm{J}-\mathrm{CN}$. In- vitro and In -vivo anti-salmonella evaluation of pectin extracts and hydrolysates from "cas mango" (Spondias dulcis). Evid Based Complem Altert Med. 2019;2019:3578402. doi: 10.1155/2019/3578402

25. Saklani S, Chandra S, Badoni PP, Dogra S. Antimicrobial activity, nutritional profile and phyto-chemical screening of wild fruit of Rubus ellipticus. Int J Med Arom Plants. 2012;2:269-274.

26. Babahmad RA, Aghraaz A, Boutafda A, et al. Chemical composition of essential oil of Jatropha curcas $\mathrm{L}$. Leaves and its antioxidant and antimicrobial activities. 
Ind Crops Prod. 2018;121(1):405-410. doi: 10.1016/j. indcrop.2018.05.030

27. Qadir U, Paul VI, Ganesh P. Preliminary Phytochemical screening and invitro antibacterial activity of Anamirta Cocculus (Linn) seeds. J King Saud Univ Sci. 2015;27(2):97-104. doi: 10.1016/j.jksus.2014.04.004

28. AhmedY, Hayashi S, Levine A, Wieschaus E. Regulation of armadillo by a Drosophila APC inhabits neuronal apoptosis during retainal development. Cell. 1998;26;93(7):1171-82. doi: 10.1016/s00928674(00)81461-0

29. Panda SK, Das R, Leyssen P, Neyts J, Luyten W. Assessing medicinal plants traditionally used in the Chirang Reserve Forest, North-East India for antimicrobial activity. J Ethnopharmacol. 2018;225:220-233. doi: 10.1016/j.jep.2018.07.011

30. Vlietinck AJ, Hoof LV, Totte J, et al. Screening of hundred
Rwandese medicinal plants for antimicrobial and antiviral properties. J Ethnopharmacol. 1995;46(1):31-47. doi: 10.1016/0378-8741(95)01226-4

31. Kitsberger CSG, Smamia J, Pedrosa RC, Ferreira SRS. Antioxidant and Antimicrobial activities of shitake (Lentinula edodes) extract obtained by organic solvents and supercritical fluids. J Food Eng. 2007;80(2):631638. doi: 10.1016/j.jfoodeng.2006.06.013

32. Radovanovic $B C$, Andelkovic ASM, Radovanovic AB, Andelkovic MZ. Antioxidant and Antimicrobial activity of polyphenol extracts from berry fruit grown in South East Serbia. Trop J Pharm Res. 2013;12(5):813-819. doi: 10.4314/tjpr.v12i5.23

33. Islary A, Sarmah J, Basumatary S. Antimicrobial property and Anti-nutritional contents of five wild fruits of Assam. Ind J Appl Pharm Sci. 2018;8(12):170175. doi: 10.7324/JAPS.2018.81220 